\title{
Familial partial lipodystrophy, Köbberling type
}

INSERM

\section{Source}

INSERM. (1999). Orphanet: an online rare disease and orphan drug data base. Familial partial lipodystrophy, Köbberling type. ORPHA:79084

Familial partial lipodystrophy, Köbberling type, is a very rare form of familial partial lipodystrophy (FPLD; see this term) of unknown etiology characterized by lipoatrophy that is confined to the limbs and a normal or increased fat distribution of the face, neck, and trunk. Arterial hypertension and diabetes have also been associated. Inheritance is thought to be autosomal dominant. 